\title{
Isothermal Titration Calorimetry to Explore the Parameter Space of Organophosphorus Agrochemical Adsorption in MOFs
}

Riki J. Drout, ${ }^{1}$ Satoshi Kato, ${ }^{1}$ Haoyuan Chen, ${ }^{2}$ Florencia A. Son, ${ }^{1}$ Ken-ichi Otake, ${ }^{1}{ }^{\dagger}$ Timur Islamoglu, ${ }^{1}$ Randall Q. Snurr, ${ }^{2}$ and Omar K. Farha ${ }^{1,2 *}$

${ }^{1}$ Department of Chemistry and International Institute for Nanotechnology, and ${ }^{2}$ Department of Chemical and Biological Engineering, Northwestern University, 2145 Sheridan Road, Evanston, IL, USA 60208

\section{Table of Contents}

MOF Syntheses

S3

MOF Characterization. .55

Figure

S1.

PXRD

Patterns

of

MOFs. S5

Figure S2. $\mathrm{N}_{2}$ Isotherms and Pore Size Distributions for NU-1000 and NU-1000NDC .................S5

Figure S3. $\mathrm{N}_{2}$ Isotherms and Pore Size Distributions for NU-901 and NU-901NDC ....................S6

Figure S4. $\quad \mathrm{N}_{2}$ Isotherm and Pore Size Distribution for NU1200 .S6

Table S1. Isotherm $\quad$ Data for

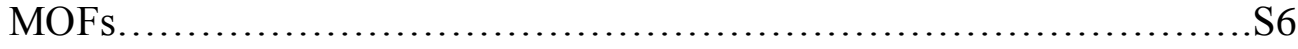

$\begin{array}{lllll}\text { Figure } & \text { S5. } & \text { SEM } & \text { Images }\end{array}$

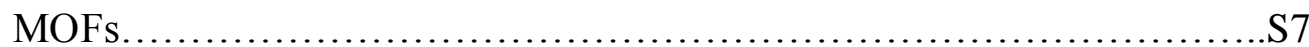

$\begin{array}{lllllll}\text { Figure } & \mathrm{S} 6 & \mathrm{~N} & \text { Isotherms } & \text { for } & \text { MOFs } & \text { Exposed }\end{array}$

Buffer. .S7 
Figure S7. NMR Spectra for NU-1000-NDC and NU-1000-NDCGly...................................S 8

Figure S8. NMR Spectra for NU-901-NDC and NU-901-NDC-

Gly ...S8

Figure

S9. Preliminary

Crystallographic

Data

for

NU-1000-

Gly S9

Bulk Adsorption Measurements. S10

Figure S10. Uptake vs. time plots for all analyte-MOF pairs S10

Table S2. Parameters for Glyphosate Adsorption on NU1000 ..S11

Table S3. Parameters for Ethylphosphonic Acid Adsorption on NU-1000

\begin{tabular}{|c|c|c|c|c|c|c|}
\hline $\begin{array}{l}\text { Table } \\
1000 . .\end{array}$ & S4. & Parameters & $\begin{array}{l}\text { for } \\
\ldots . . S 11\end{array}$ & Glufosinate & Adsorption & on \\
\hline $\begin{array}{l}\text { Table } \\
901 \ldots\end{array}$ & S5. & Parameters & $\begin{array}{l}\text { for } \\
\ldots . \mathrm{S} 11\end{array}$ & Glyphosate & Adsorption & on \\
\hline $\begin{array}{l}\text { Table } \\
1200 .\end{array}$ & S6. & Parameters & $\begin{array}{l}\text { for } \\
\ldots \text {.S12 }\end{array}$ & Glyphosate & Adsorption & on \\
\hline
\end{tabular}

Figure S11. Relationship Between Initial Concentrations and Partition Coefficients.... $\mathrm{S} 12$

Figure S12. Linear Langmuir Fits for Organophosphorus Agrochemicals Adsorbing to NU$1000 \ldots . . . . S 12$

Figure S13. Linear Langmuir Fits for Glyphosate Adsorbing to $\mathrm{Zr}$ MOFs. S13

Isothermal Titration Calorimetry.

S14

Table S7. Isothermal Titration Calorimetry Experiment Details. . $\mathrm{S} 14$

$\begin{array}{llllll}\text { Figure } & \text { S14. } & \text { ITC } & \text { Thermograms } & \text { for } & \text { Control }\end{array}$

Experiments. S14

Figure S15. ITC Thermograms for Organophosphorus Analytes Adsorbing to NU1000 . S15

Figure S16. Thermodynamic Parameters of Organophosphorus Analytes Adsorbing to NU$1000 \ldots \ldots . . . . S 15$ 
Table S8. Thermodynamic Parameters of Ethylphosphonic Acid Adsorbing to Zr-MOFs.... S16

Figure S17. Thermodynamic Parameters of Ethylphosphonic Acid Adsorbing to NU-1000 and NU-1000-NDC

$\mathrm{S} 16$

Figure S18. Thermodynamic Parameters of Glyphosate and Ethylphosphonic Acid Adsorbing to NU901 and

NU-901-

NDC. $\mathrm{S} 17$

Figure S19. Linear Relationship Between Thermodynamic Parameters and Buffer Concentration......S17

DFT

Energy-Minimized

Structures S18

Figure S20. Structures of Ethylphosphonic Acid Coordinated to NU-1000 Node S18

Figure S21. Structures of Glufosinate Coordinate to NU-1000 Node S18

Figure S22. Structure of Glyphosate Coordinated to the NU-901 Node.................................S18 


\section{MOF Syntheses}

Synthesis of NU-1000. 4,4',4",4"'-(pyrene-1,3,6,8-tetrayl)tetrabenzoate $\left(\mathrm{H}_{4}\right.$ TBAPy) was synthesized according to the reported procedure. ${ }^{1}$ The MOF was prepared according to an established procedure. ${ }^{2}$ Briefly, $\mathrm{ZrOCl}_{2} \cdot 8 \mathrm{H}_{2} \mathrm{O}(9.7 \mathrm{~g}, 30 \mathrm{mmol})$ and benzoic acid $(200 \mathrm{~g}, 1.6 \mathrm{~mol})$ were added to $600 \mathrm{~mL}$ of $\mathrm{DMF}$ in a $2 \mathrm{~L}$ glass bottle. The mixture was sonicated until clear and then heated for $1 \mathrm{~h}$ in a preheated oven at $100{ }^{\circ} \mathrm{C}$. Similarly, $\mathrm{H}_{4}$ TBAPy $(4 \mathrm{~g}, 6 \mathrm{mmol})$ was added to $200 \mathrm{~mL}$ of DMF in a $500 \mathrm{~mL}$ glass bottle and heated for $1 \mathrm{~h}$ in a preheated oven at $100{ }^{\circ} \mathrm{C}$. After cooling to room temperature, trifluoroacetic acid (TFA) $(4 \mathrm{~mL}, 52 \mathrm{mmol})$ was added to the prepared $\mathrm{Zr}$-solution. After sonicating for $15 \mathrm{~min}$, the linker solution was added to the $\mathrm{Zr}$-solution and then heated at $120{ }^{\circ} \mathrm{C}$ for $18 \mathrm{~h}$. After cooling down to room temperature, the yellow powder was isolated by centrifugation ( $5 \mathrm{~min}, 7500 \mathrm{rpm}$ ) and washed with fresh DMF $(\sim 300 \mathrm{~mL})$ three times for $2 \mathrm{~h}$ each. The resulting yellow powder was suspended in $1300 \mathrm{~mL}$ DMF in a $2 \mathrm{~L}$ glass jar and $50 \mathrm{~mL}$ of $8 \mathrm{M}$ aqueous $\mathrm{HCl}$ was added. The mixture was heated in an oven at $100{ }^{\circ} \mathrm{C}$ for $18 \mathrm{~h}$. After cooling to room temperature, the powder was washed with fresh DMF $(\sim 300 \mathrm{~mL})$ three times for $2 \mathrm{~h}$ each and acetone $(\sim 300 \mathrm{~mL})$ three times for $2 \mathrm{~h}$ each and soaked in acetone for additional $18 \mathrm{~h}$. The NU-1000 powder was collected by centrifugation and dried in a vacuum oven at $80^{\circ} \mathrm{C}$ for $2 \mathrm{~h}$, and then thermally activated on a Smart VacPrep at $120{ }^{\circ} \mathrm{C}$ for $18 \mathrm{~h}$.

Synthesis of NU-901. 4,4',4",4"'-(pyrene-1,3,6,8-tetrayl)tetrabenzoate $\left(\mathrm{H}_{4} \mathrm{TBAPy}\right)$ was synthesized according to the reported procedure. ${ }^{1}$ NU-901 was synthesized according to an established procedure with slight modifications. ${ }^{3}$ To a clean $100 \mathrm{~mL}$ glass jar, 4-aminobenzoic acid $(15.1 \mathrm{~g}, 0.110 \mathrm{~mol})$ and DMF $(40 \mathrm{~mL})$ were added. After sonicating for $5 \mathrm{~min}$, the jar was placed in an oven preheated to $80{ }^{\circ} \mathrm{C}$ for $30 \mathrm{~min}$ to fully dissolve the modulator. To the clear solution, $\operatorname{Zr}(\mathrm{acac})_{4}$ (acac $=$ acetylacetonate) $(0.485 \mathrm{~g}, 0.995 \mathrm{mmol})$ was added. The mixture was sonicated for $5 \mathrm{~min}$ and placed in an oven preheated to $80{ }^{\circ} \mathrm{C}$ for $1 \mathrm{~h}$. After cooling the solution to room temperature, $\mathrm{H}_{4}$ TBAPy $(0.200 \mathrm{~g}, 0.3 \mathrm{mmol})$ was added to the jar. The solution was sonicated for $10 \mathrm{~min}$ and then distributed equally between five 8 -dram vials. The vials were capped and placed in an oven preheated to $100{ }^{\circ} \mathrm{C}$ for $18 \mathrm{~h}$. After cooling down to room temperature, the yellow powder was isolated by centrifugation $(5 \mathrm{~min}, 7500 \mathrm{rpm})$ and washed with fresh DMF $(\sim 30 \mathrm{~mL})$ three times for $2 \mathrm{~h}$ each. To remove monotopically bound 4-aminobenzoic acid, the resulting yellow powder (from all 5 vials) was suspended in $20 \mathrm{~mL}$ of DMF in a $250 \mathrm{~mL}$ glass jar. In a separate jar, a mixture of $8 \mathrm{M} \mathrm{HCl}(2.5 \mathrm{~mL})$ and DMF $(40 \mathrm{~mL})$ was prepared. After swirling this solution, it was poured into the $250 \mathrm{~mL}$ jar containing the MOF. The mixture was sonicated for $5 \mathrm{~min}$ and then placed in an oven preheated to $80{ }^{\circ} \mathrm{C}$ for $18 \mathrm{~h}$. After cooling to room temperature, the powder was washed with fresh DMF $(\sim 30 \mathrm{~mL})$ three times for $2 \mathrm{~h}$ each and acetone $(\sim 30 \mathrm{~mL})$ three times for $2 \mathrm{~h}$ each and soaked in acetone $(30 \mathrm{~mL})$ for additional $18 \mathrm{~h}$. The NU-901 powder was collected by centrifugation and dried in a vacuum oven at $80{ }^{\circ} \mathrm{C}$ for $2 \mathrm{~h}$, and then thermally activated on a Smart VacPrep at $120^{\circ} \mathrm{C}$ for $18 \mathrm{~h}$.

Synthesis of NU-1200. 4,4',4"'-(2,4,6-trimethylbenzene-1,3,5-triyl)tribenzoic acid (TMTB) was synthesized according to a reported procedure. ${ }^{4}$ The MOF was synthesized as follows: TMTB linker $(0.02 \mathrm{mmol}, 10 \mathrm{mg})$ and $\mathrm{ZrOCl}_{2} \cdot 8 \mathrm{H}_{2} \mathrm{O}(17 \mathrm{mg}, 0.07 \mathrm{mmol})$ were added to a 4 dram vial and dissolved in $2 \mathrm{~mL}$ of DMF. The mixture was then sonicated for $10 \mathrm{~min}$. Then, TFA $(150 \mu \mathrm{L})$ was added to the solution. After sonicating for $5 \mathrm{~min}$, the solution was placed in an oven preheated to $120{ }^{\circ} \mathrm{C}$ for $24 \mathrm{~h}$. After cooling to room temperature, the MOF powder was isolated by centrifugation and washed three times with DMF $(12 \mathrm{~mL}$ ) for $10 \mathrm{~min}$. The MOF powder was then dispersed in $12 \mathrm{~mL}$ of DMF in an 8dram vial and $500 \mu \mathrm{L}$ of $4 \mathrm{M} \mathrm{HCl}$ was added. After sonicating the mixture for $5 \mathrm{~min}$, the vial was placed 
in an oven preheated to $100{ }^{\circ} \mathrm{C}$ for $24 \mathrm{~h}$. After cooling to room temperature, the MOF was isolated by centrifugation and washed three times with $\mathrm{DMF}(12 \mathrm{~mL})$ for $1 \mathrm{~h}$ and three times with acetone $(12 \mathrm{~mL})$ for $1 \mathrm{~h}$. The MOF powder was then soaked in acetone $(12 \mathrm{~mL})$ for $18 \mathrm{~h}$ overnight. The NU-1200 powder was collected by centrifugation and dried in a vacuum oven at $80{ }^{\circ} \mathrm{C}$ for $2 \mathrm{~h}$, and then thermally activated on a Smart VacPrep at $120^{\circ} \mathrm{C}$.

Solvent-Assisted Ligand Incorporation (SALI). SALI experiments were performed according to an established procedure. ${ }^{5}$ Briefly, activated MOF (200 mg, $0.091 \mathrm{mmol}$ ) and 2,6-naphthalenedicarboxylic acid (79 $\mathrm{mg}, 0.37 \mathrm{mmol}$ ) were dispersed in $10 \mathrm{~mL}$ of DMF in an 8-dram glass vial. The mixture was sonicated for $15 \mathrm{~min}$ and then heated for $18 \mathrm{~h}$ in an oven at $80{ }^{\circ} \mathrm{C}$. After cooling to room temperature, the powder was isolated by centrifugation $(5 \mathrm{~min}, 7500 \mathrm{rpm})$. The powder was soaked three times in fresh DMF (12 mL) for $2 \mathrm{~h}$. The yellow powder was then dispersed in $48 \mathrm{~mL}$ of fresh DMF and $2 \mathrm{~mL}$ of $8 \mathrm{M} \mathrm{HCl}$ were added to the mixture. After sonicating for $15 \mathrm{~min}$, the vial was heated for $18 \mathrm{~h}$ in an oven at $60{ }^{\circ} \mathrm{C}$. The powder was soaked three times in fresh DMF $(40 \mathrm{~mL})$ for $2 \mathrm{~h}$ and three times in acetone $(40 \mathrm{~mL})$ for $2 \mathrm{~h}$. After soaking for $18 \mathrm{~h}$ in acetone, the MOF powder was isolated by centrifugation (5 min, $7500 \mathrm{rpm}$ ), dried in a vacuum oven at $80{ }^{\circ} \mathrm{C}$, and finally thermally activated on a Smart VacPrep at $100{ }^{\circ} \mathrm{C}$ for $18 \mathrm{~h}$. The NDC loading was determined by nuclear magnetic resonance (NMR) spectroscopy. 


\section{Characterization}
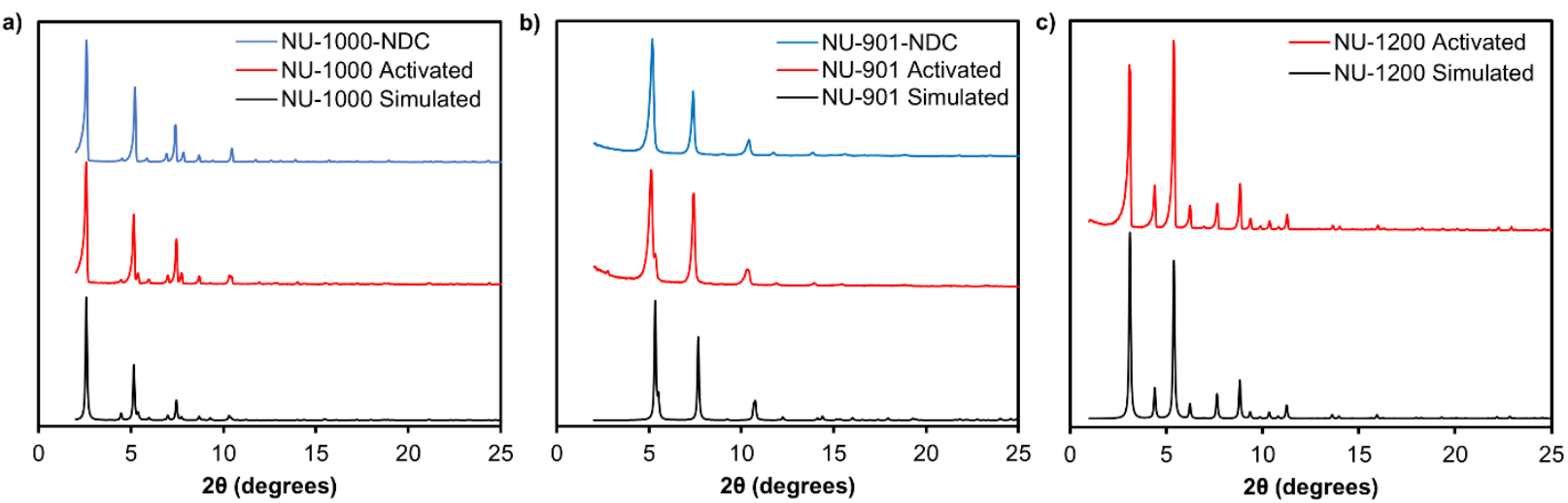

Figure S1. PXRD patterns of a) NU-1000 and NU-1000-NDC, b) NU-901 and NU-901-NDC, and c) NU-1200.
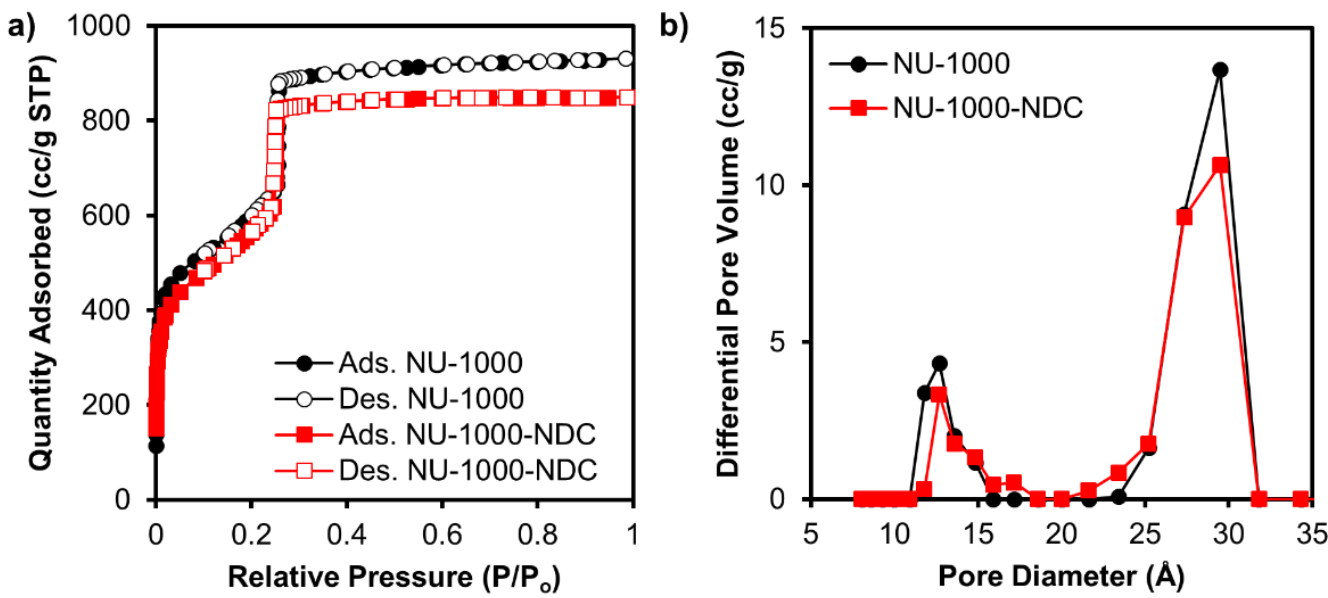

Figure S2. a) Nitrogen adsorption-desorption isotherms at $77 \mathrm{~K}$ and b) DFT-calculated pore size distribution of NU-1000 and NU-1000-NDC. 

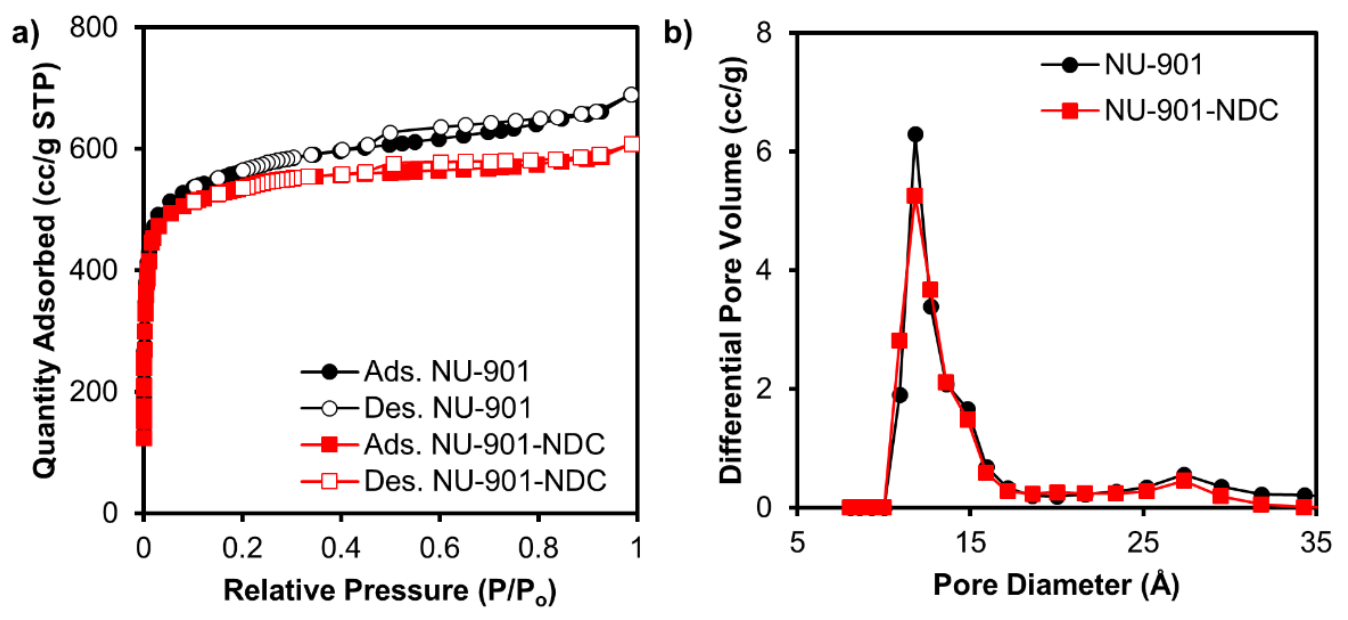

Figure S3. a) Nitrogen adsorption-desorption isotherms at $77 \mathrm{~K}$ and b) DFT-calculated pore size distribution of NU-901 and NU-901-NDC.
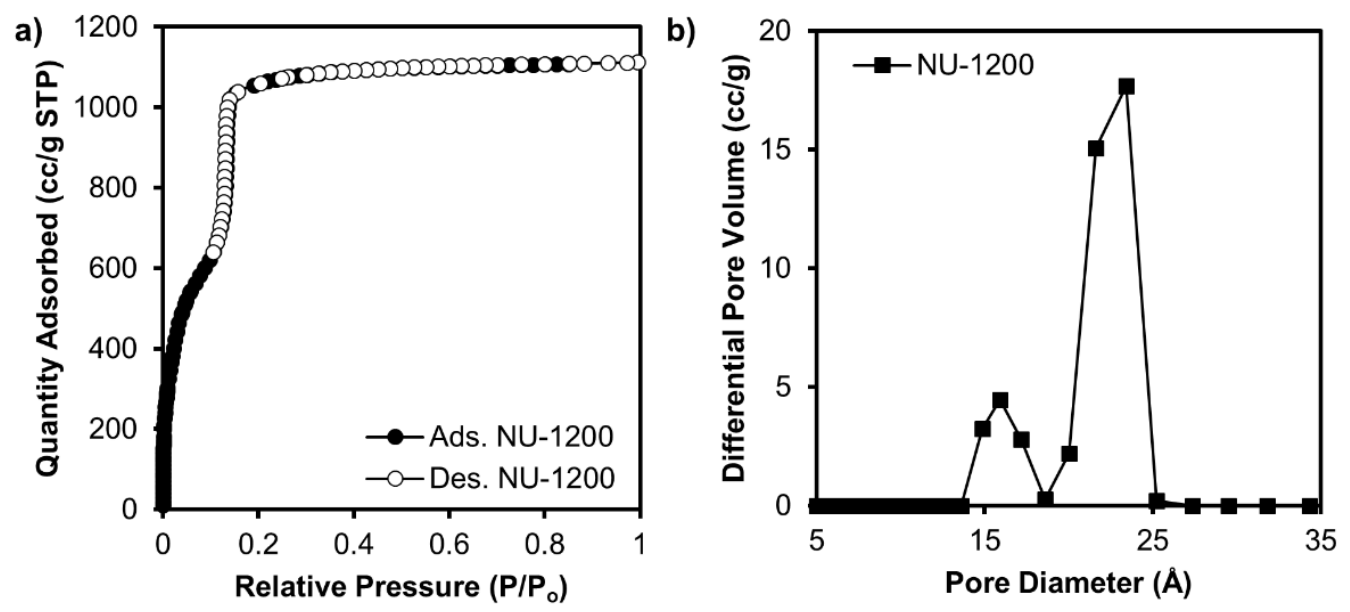

Figure S4. a) Nitrogen adsorption-desorption isotherms at $77 \mathrm{~K}$ and b) DFT-calculated pore size distribution of NU-1200.

Table S1. Nitrogen isotherm data, topologies, and node connectivity for $\mathrm{Zr}_{6}-\mathrm{MOFs}$.

\begin{tabular}{ccccc}
\hline MOF & $\begin{array}{c}\text { Surface Area } \\
\mathbf{m}^{\mathbf{2}} \mathbf{g}^{-\mathbf{1}}\end{array}$ & $\begin{array}{c}\text { Pore Size(s) } \\
\mathbf{A}\end{array}$ & $\begin{array}{c}\text { Node } \\
\text { Connectivity }\end{array}$ & Topology \\
\hline NU-1000 & 2050 & 13,30 & 8 & csq \\
\hline NU-1000-NDC & 1870 & 13,30 & 10 & csq \\
\hline NU-901 & 2180 & 12 & 8 & scu \\
\hline NU-901-NDC & 2090 & 12 & 10 & scu \\
\hline NU-1200 & 2710 & 16,23 & 8 & the \\
\hline
\end{tabular}




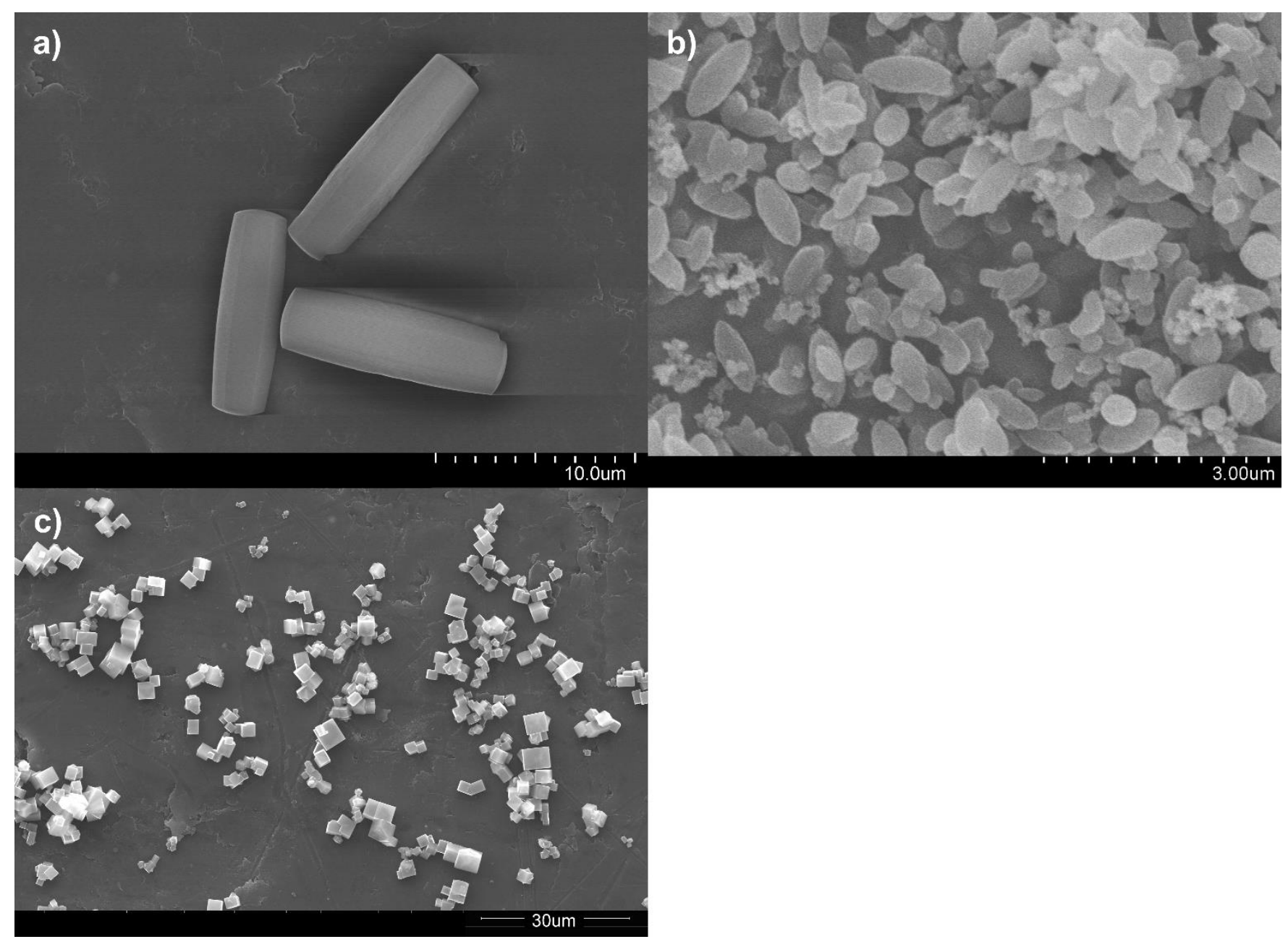

Figure S5. SEM images of a) NU-1000, b) NU-901, and c) NU-1200.

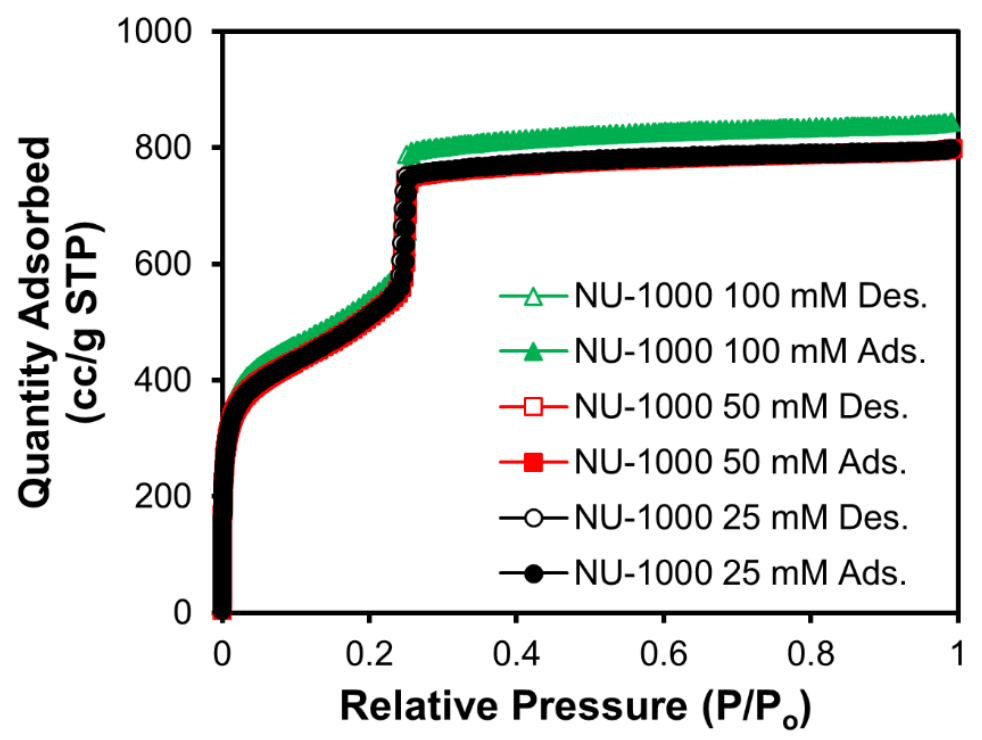

Figure S6. Nitrogen adsorption-desorption isotherms at $77 \mathrm{~K}$ for NU-1000 soaked in $25 \mathrm{mM}$ (black, BET area: $1740 \mathrm{~m}^{2} \mathrm{~g}^{-1}$ ), $50 \mathrm{mM}$ (red, BET surface area: $1740 \mathrm{~m}^{2} \mathrm{~g}^{-1}$ ), and $100 \mathrm{mM}$ (green, BET area: $1850 \mathrm{~m}^{2} \mathrm{~g}^{-1}$ ) acetate buffer ( $\left.\mathrm{pH} 4\right)$ for 3 days. 

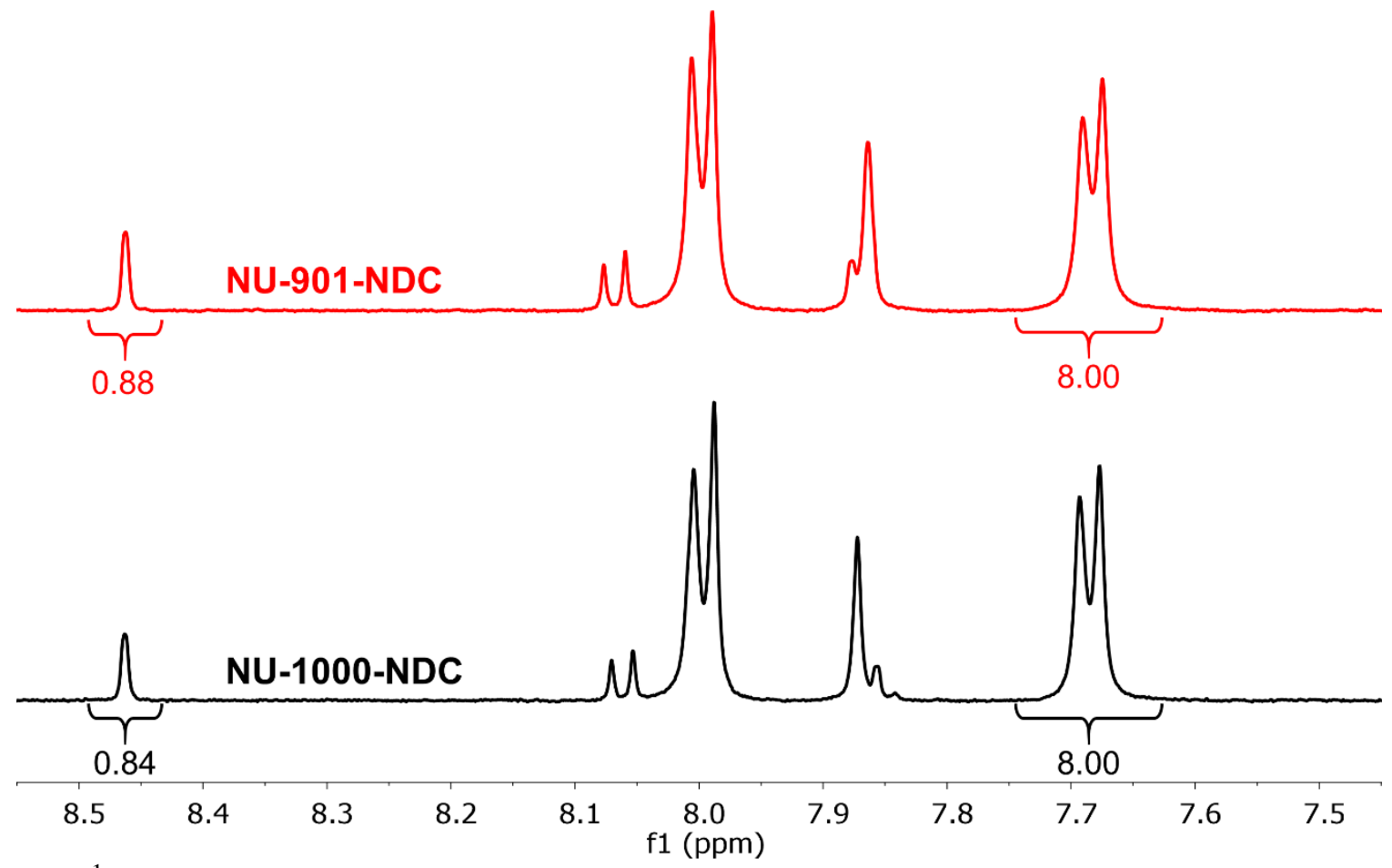

Figure S7. ${ }^{1} \mathrm{H}$ NMR spectra depicting the incorporation of 2,6-naphthalene dicarboxylic acid into the cpores of NU-1000 (black trace) and NU-901 (red trace).

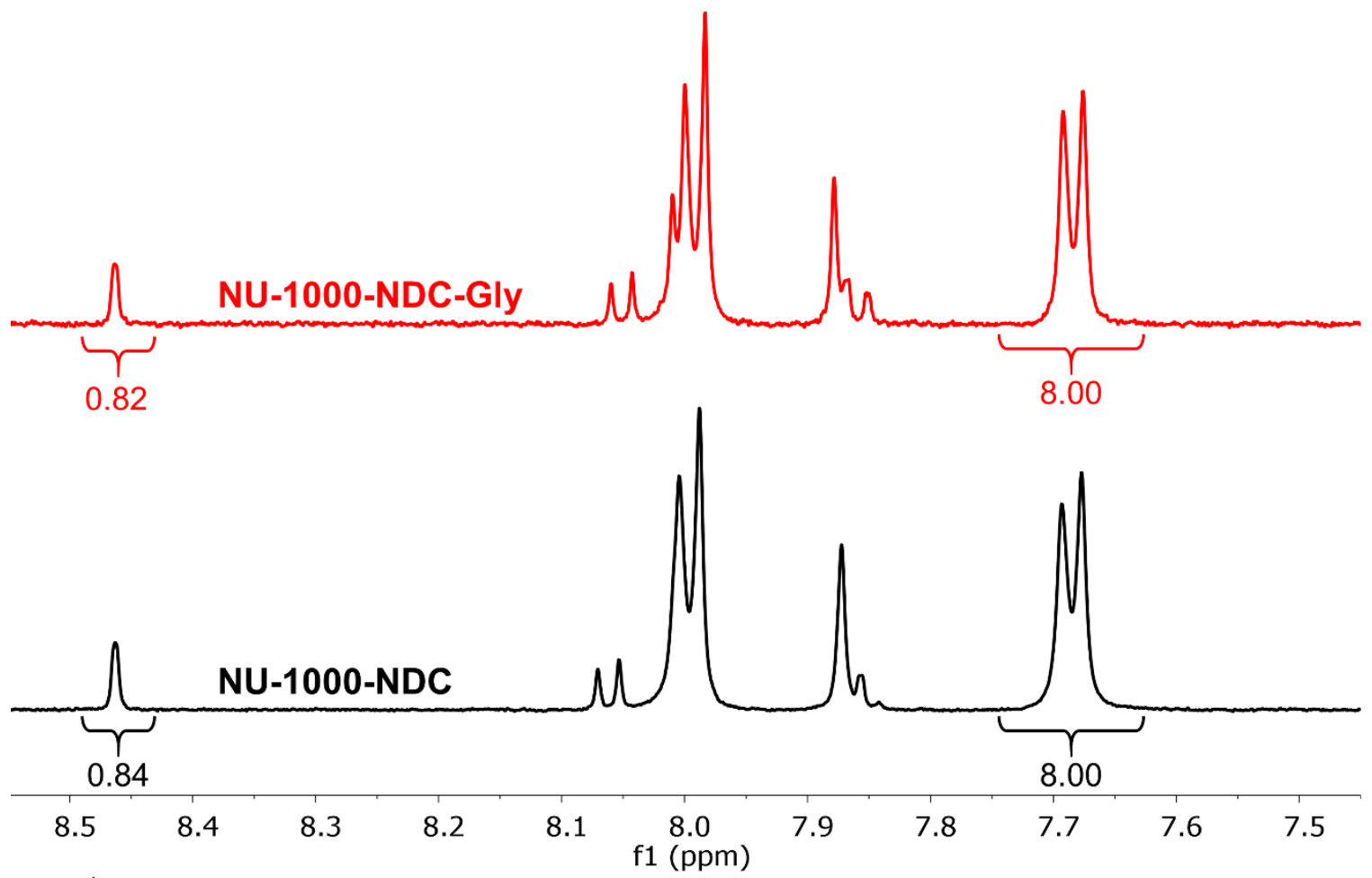

Figure S8. ${ }^{1} \mathrm{H}$ NMR spectra of NU-1000-NDC before (black trace) and after (red trace) exposure to glyphosate verifying that glyphosate does not substantially displace the 2,6-naphthalene dicarboxylic acid installed in the c-pores. 

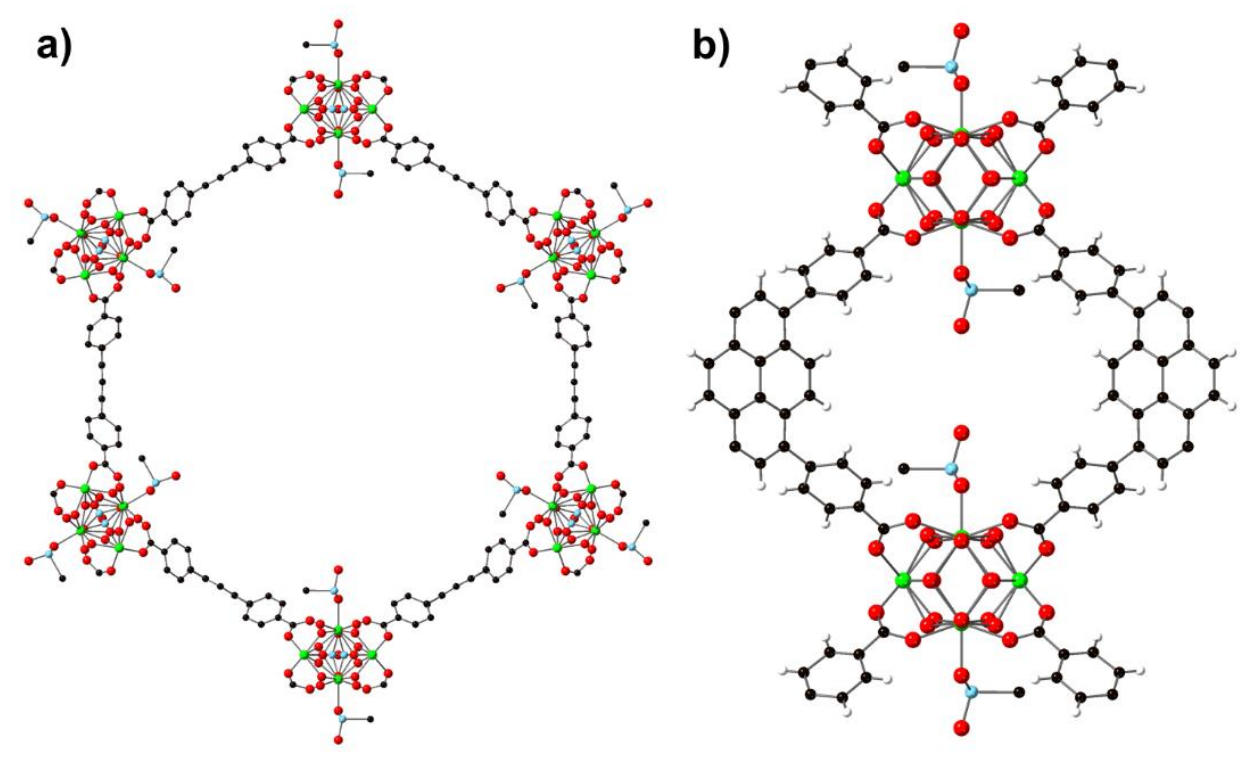

Figure S9. Preliminary crystallographic data suggested $35 \%$ of the coordinated glyphosate binds at sites directed into the a) hexagonal mesopore, while the remaining $65 \%$ binds at sites directed into the b) c-pore. Green, black, red, white, and blue spheres represent $\mathrm{Zr}, \mathrm{C}, \mathrm{O}, \mathrm{H}$, and $\mathrm{P}$ atoms, respectively. 


\section{Bulk Adsorption Experiments}
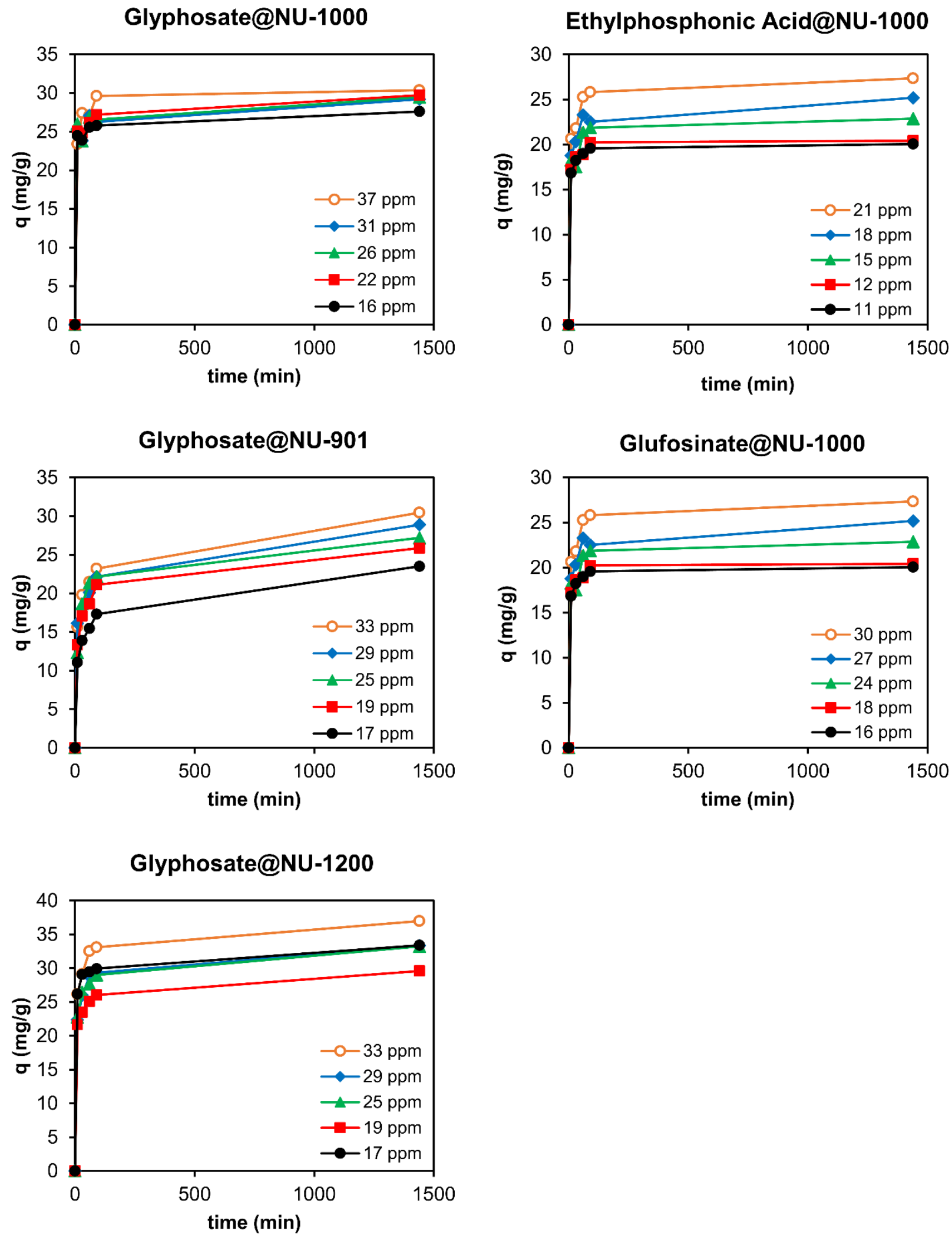

Figure S10. Plots of phosphorus uptake (mg/g) vs. time for each analyte-MOF pair. 
Table S2. Initial and final concentrations of glyphosate, uptake capacity of NU-1000, and respective partition coefficients.

\begin{tabular}{cccc}
\hline $\begin{array}{c}\text { Initial Concentration } \\
\mathbf{P}(\mathbf{m g} / \mathbf{L})\end{array}$ & $\begin{array}{c}\text { Final Concentration, } \mathbf{C}_{\mathbf{e}} \\
\mathbf{P}(\mathbf{m g} / \mathbf{L})\end{array}$ & $\begin{array}{c}\text { Uptake, } \mathbf{q}_{\mathbf{e}} \\
(\mathbf{m g} / \mathbf{g})\end{array}$ & $\begin{array}{c}\text { Partition Coefficient, } \mathbf{q}_{\mathbf{e}} / \mathbf{C}_{\mathbf{e}} \\
(\mathbf{L} / \mathbf{g})\end{array}$ \\
\hline 16.4 & 5.39 & 27.6 & 5.13 \\
\hline 21.7 & 9.85 & 29.7 & 3.02 \\
\hline 25.9 & 14.1 & 29.5 & 2.10 \\
\hline 30.7 & 19.0 & 29.2 & 1.54 \\
\hline 36.5 & 24.4 & 30.4 & 1.25 \\
\hline
\end{tabular}

Table S3. Initial and final concentrations of ethylphosphonic acid, uptake capacity of NU-1000, and respective partition coefficients.

\begin{tabular}{cccc}
\hline $\begin{array}{c}\text { Initial Concentration } \\
\mathbf{P}(\mathbf{m g} / \mathbf{L})\end{array}$ & $\begin{array}{c}\text { Final Concentration, } \mathbf{C}_{\mathbf{e}} \\
\mathbf{P}(\mathbf{m g} / \mathbf{L})\end{array}$ & $\begin{array}{c}\text { Uptake, } \mathbf{q}_{\mathbf{e}} \\
(\mathbf{m g} / \mathbf{g})\end{array}$ & $\begin{array}{c}\text { Partition Coefficient, } \mathbf{q}_{\mathbf{e}} / \mathbf{C}_{\mathbf{e}} \\
(\mathbf{L} / \mathbf{g})\end{array}$ \\
\hline 11.1 & 3.08 & 20.1 & 6.53 \\
\hline 12.2 & 4.01 & 20.4 & 5.10 \\
\hline 15.0 & 5.83 & 22.9 & 3.92 \\
\hline 17.8 & 7.66 & 25.2 & 3.29 \\
\hline 20.7 & 9.80 & 27.4 & 2.79 \\
\hline
\end{tabular}

Table S4. Initial and final concentrations of glufosinate, uptake capacity of NU-1000, and respective partition coefficients.

\begin{tabular}{cccc}
\hline $\begin{array}{c}\text { Initial Concentration } \\
\mathbf{P}(\mathbf{m g} / \mathbf{L})\end{array}$ & $\begin{array}{c}\text { Final Concentration, } \mathbf{C}_{\mathbf{e}} \\
\mathbf{P}(\mathbf{m g} / \mathbf{L})\end{array}$ & $\begin{array}{c}\text { Uptake, } \mathbf{q}_{\mathbf{e}} \\
(\mathbf{m g} / \mathbf{g})\end{array}$ & $\begin{array}{c}\text { Partition Coefficient, } \mathbf{q}_{\mathbf{e}} / \mathbf{C}_{\mathbf{e}} \\
(\mathbf{L} / \mathbf{g})\end{array}$ \\
\hline 16.0 & 8.07 & 19.9 & 2.46 \\
\hline 18.0 & 9.59 & 21.0 & 2.19 \\
\hline 23.7 & 13.6 & 25.4 & 1.87 \\
\hline 26.7 & 16.8 & 24.7 & 1.47 \\
\hline 30.2 & 20.0 & 25.3 & 1.26 \\
\hline
\end{tabular}

Table S5. Initial and final concentrations of glyphosate, uptake capacity of NU-901, and respective partition coefficients.

\begin{tabular}{cccc}
\hline $\begin{array}{c}\text { Initial Concentration } \\
\mathbf{P}(\mathbf{m g} / \mathbf{L})\end{array}$ & $\begin{array}{c}\text { Final Concentration, } \mathbf{C}_{\mathbf{e}} \\
\mathbf{P}(\mathbf{m g} / \mathbf{L})\end{array}$ & $\begin{array}{c}\text { Uptake, } \mathbf{q}_{\mathbf{e}} \\
(\mathbf{m g} / \mathbf{g})\end{array}$ & $\begin{array}{c}\text { Partition Coefficient, } \mathbf{q}_{\mathbf{e}} / \mathbf{C}_{\mathbf{e}} \\
(\mathbf{L} / \mathbf{g})\end{array}$ \\
\hline 17.0 & 7.57 & 23.5 & 3.11 \\
\hline 19.3 & 9.00 & 25.9 & 2.87 \\
\hline 25.1 & 14.2 & 27.2 & 1.91 \\
\hline 29.5 & 17.9 & 28.9 & 1.61 \\
\hline 33.3 & 21.1 & 30.5 & 1.44 \\
\hline
\end{tabular}


Table S6. Initial and final concentrations of glyphosate, uptake capacity of NU-1200, and respective partition coefficients.

\begin{tabular}{cccc}
\hline $\begin{array}{c}\text { Initial Concentration } \\
\mathbf{P}(\mathbf{m g} / \mathbf{L})\end{array}$ & $\begin{array}{c}\text { Final Concentration, } \mathbf{C}_{\mathbf{e}} \\
\mathbf{P}(\mathbf{m g} / \mathbf{L})\end{array}$ & $\begin{array}{c}\text { Uptake, } \mathbf{q}_{\mathbf{e}} \\
(\mathbf{m g} / \mathbf{g})\end{array}$ & $\begin{array}{c}\text { Partition Coefficient, } \mathbf{q}_{\mathbf{e}} / \mathbf{C}_{\mathbf{e}} \\
(\mathbf{L} / \mathbf{g})\end{array}$ \\
\hline 17.0 & 3.61 & 33.4 & 9.25 \\
\hline 19.3 & 7.51 & 29.6 & 3.94 \\
\hline 25.1 & 11.8 & 33.2 & 2.81 \\
\hline 29.5 & 16.2 & 33.4 & 2.06 \\
\hline 33.3 & 18.5 & 37.0 & 2.00 \\
\hline
\end{tabular}
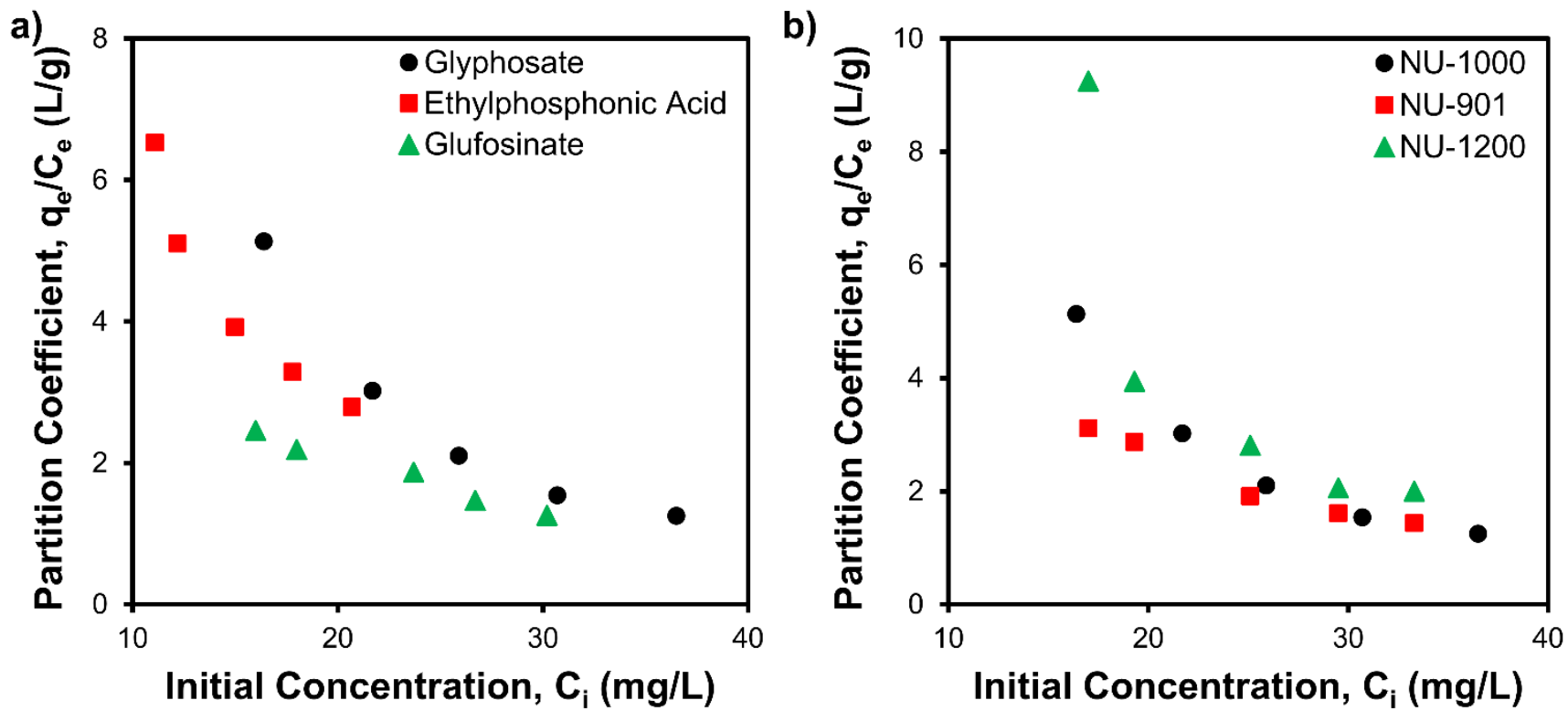

Figure S11. Relationship between initial phosphorus concentrations and partition coefficients for a) adsorption of analytes on NU-1000 and b) adsorption of glyphosate on NU-1000, NU-901, and NU1200.

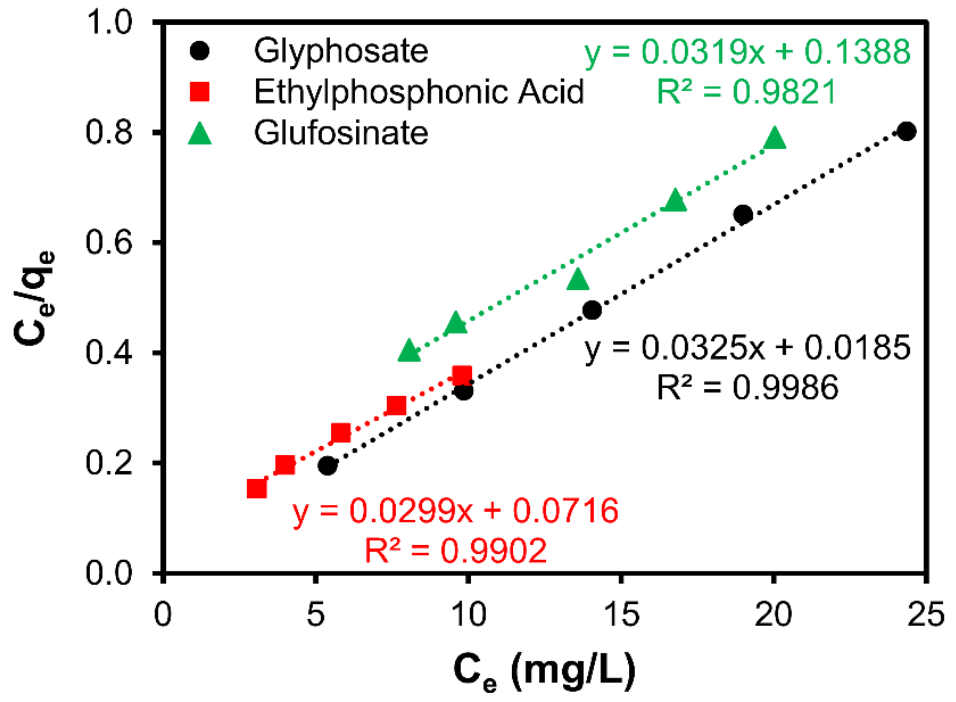

Figure S12. Langmuir fits for the capture of various analytes by NU-1000. 


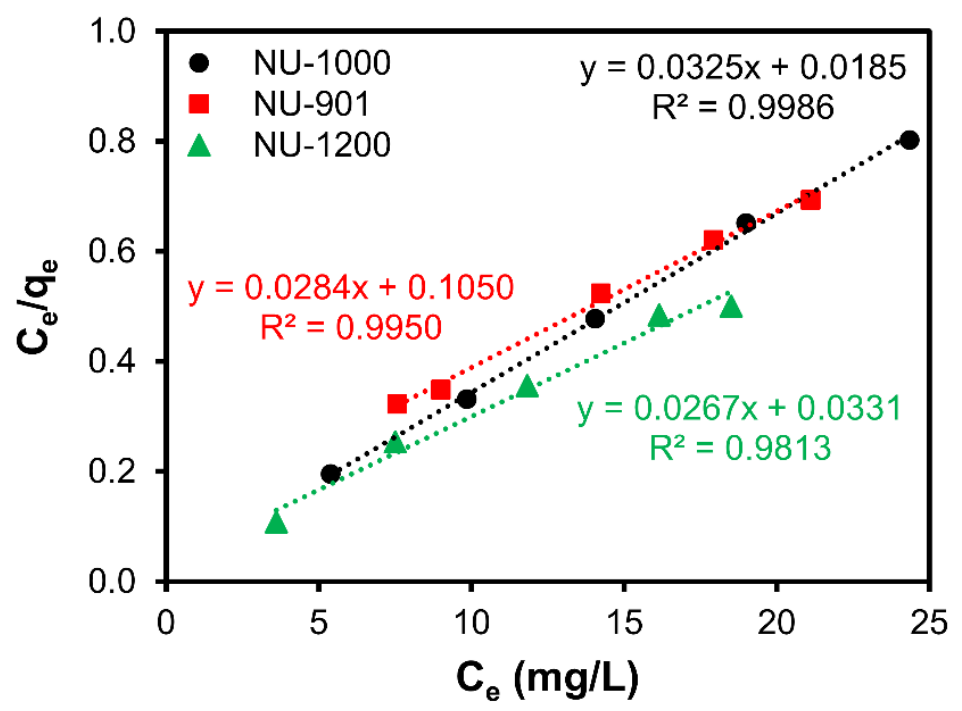

Figure S13. Langmuir fits for the capture of glyphosate by NU-1000, NU-901, and NU-1200. 


\section{Isothermal Titration Calorimetry}

Table S7. Isothermal Titration Calorimetry Measurement Conditions.

\begin{tabular}{cccccc}
\hline Analyte & $\begin{array}{c}\text { Analyte } \\
\text { Concentration } \\
(\mathbf{m M})\end{array}$ & MOF & $\begin{array}{c}\text { MOF } \\
\text { Concentration } \\
(\mathbf{m M})\end{array}$ & $\begin{array}{c}\text { Injection } \\
\text { Volume }(\boldsymbol{\mu} \mathbf{L})\end{array}$ & $\begin{array}{c}\text { Acetate Buffer } \\
\text { Matrix }(\mathbf{p H} \mathbf{4})\end{array}$ \\
\hline glyphosate & 10 & NU-1000 & 1.0 & 4 & $50 \mathrm{mM}$ \\
glyphosate & 10 & NU-1000 & 1.0 & 4 & $25 \mathrm{mM}$ \\
glyphosate & 10 & NU-1000 & 1.0 & 4 & $100 \mathrm{mM}$ \\
glyphosate & 20 & NU-1000-NDC & 1.0 & 4 & $50 \mathrm{mM}$ \\
$\begin{array}{c}\text { glyphosate } \\
\text { glyphosate } \\
\text { glyphosate }\end{array}$ & 10 & NU-901 & 0.5 & 5 & $50 \mathrm{mM}$ \\
$\begin{array}{c}\text { ethylphosphonic } \\
\text { acid }\end{array}$ & 20 & NU-901-NDC & 1.0 & 4 & $50 \mathrm{mM}$ \\
\hline $\begin{array}{c}\text { ethylphosphonic } \\
\text { acid }\end{array}$ & 10 & NU-1200 & 1.0 & 4 & $50 \mathrm{mM}$ \\
\hline $\begin{array}{c}\text { ethylphosphonic } \\
\text { acid }\end{array}$ & 10 & NU-1000 & 1.0 & 5 & $50 \mathrm{mM}$ \\
\hline $\begin{array}{c}\text { ethylphosphonic } \\
\text { acid }\end{array}$ & 20 & NU-1000-NDC & 1.0 & 4 & $50 \mathrm{mM}$ \\
\hline ethylphosphonic \\
acid
\end{tabular}
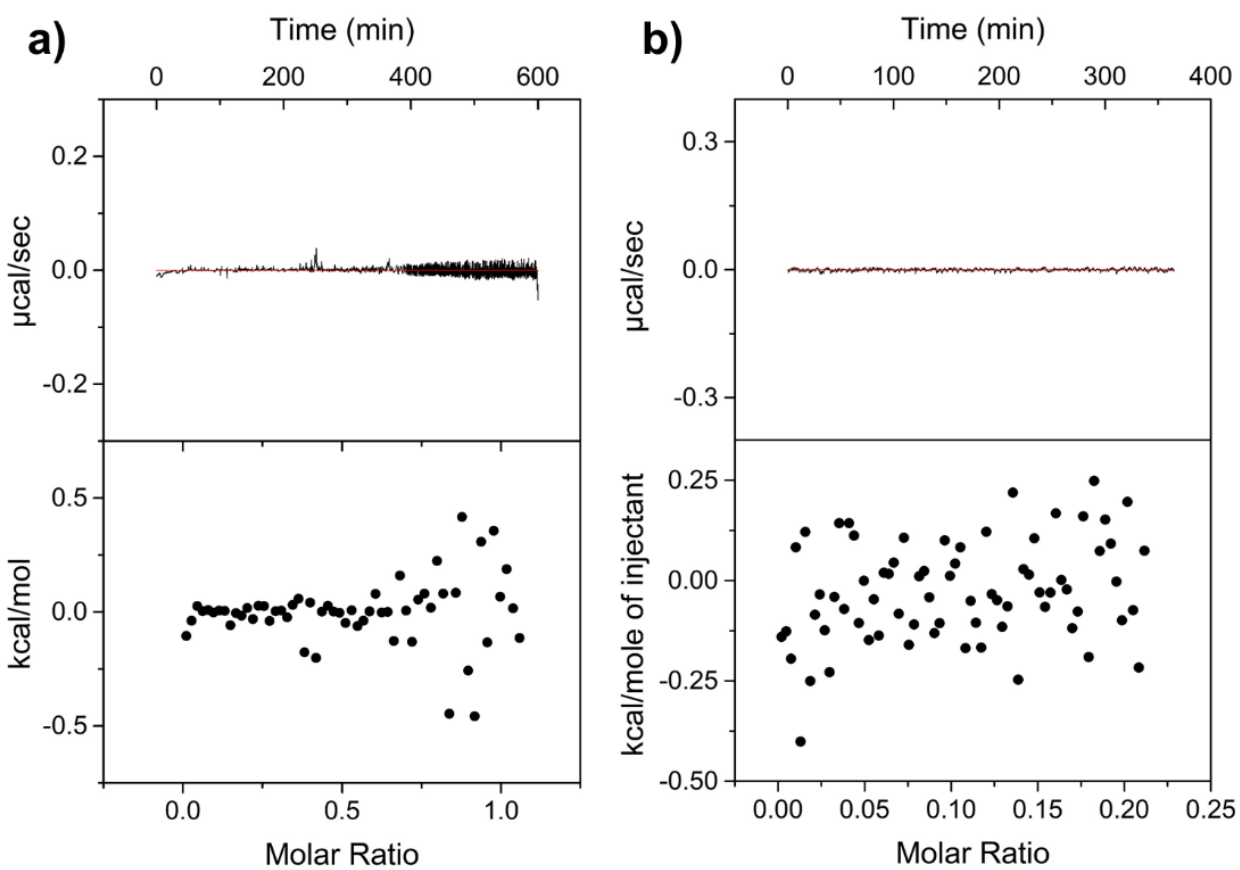

Figure S14. ITC thermograms for injections of a) glyphosate $(10 \mathrm{mM}, 50 \mathrm{mM}$ acetate buffer, $\mathrm{pH} 4)$ into acetate buffer $(50 \mathrm{mM}, \mathrm{pH} 4)$ and b) acetate buffer $(50 \mathrm{mM}, \mathrm{pH} 4)$ into a NU-1000 suspension (1 mM, $50 \mathrm{mM}$ acetate buffer, $\mathrm{pH} 4)$. 

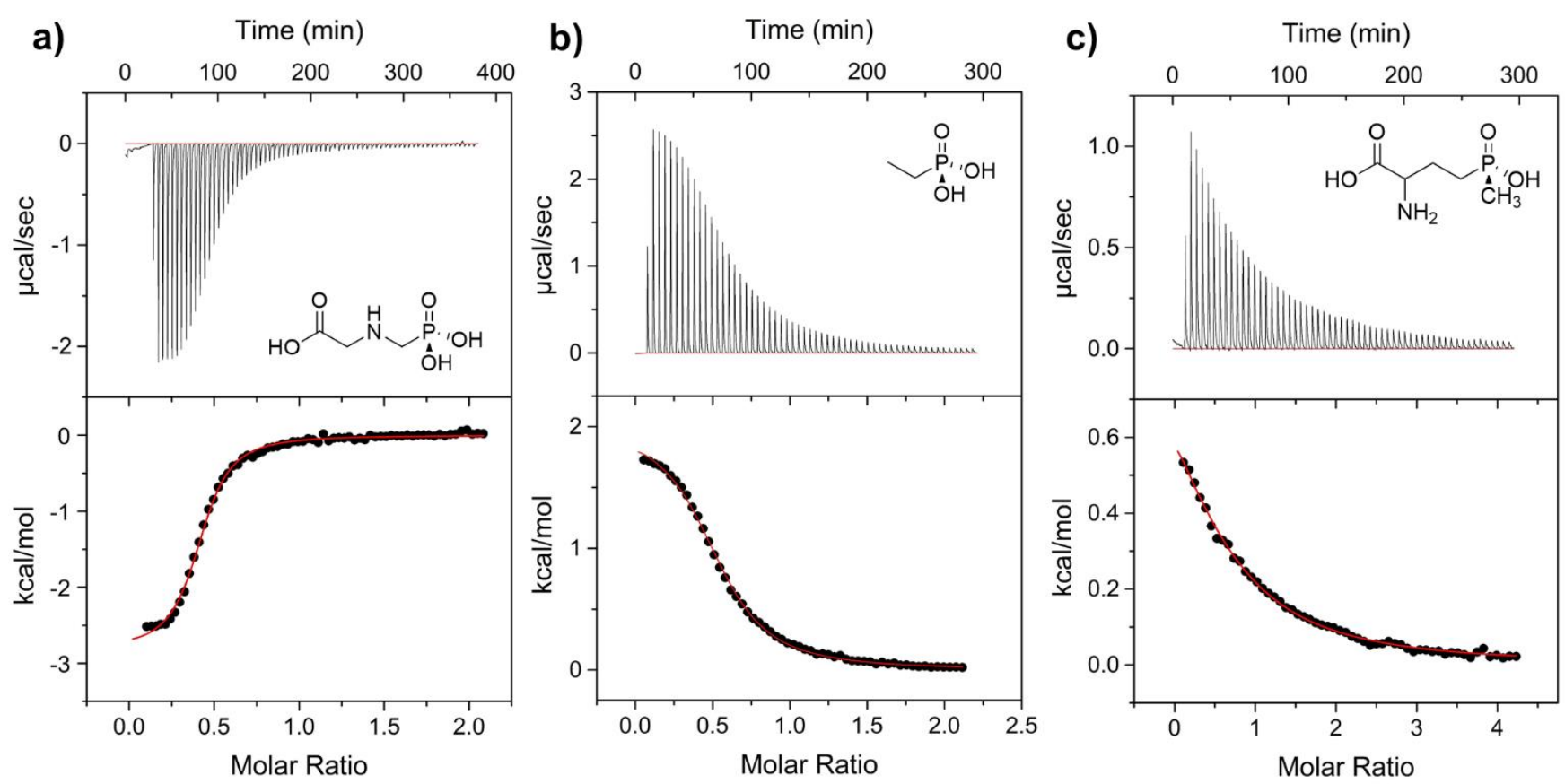

Figure S15. ITC thermograms resulting from injections of a) glyphosate, b) ethylphosphonic acid, and c) glufosinate into a NU-1000 suspension (1 mM, $1.4 \mathrm{~mL}, 50 \mathrm{mM}$ acetate buffer, $\mathrm{pH} 4)$.

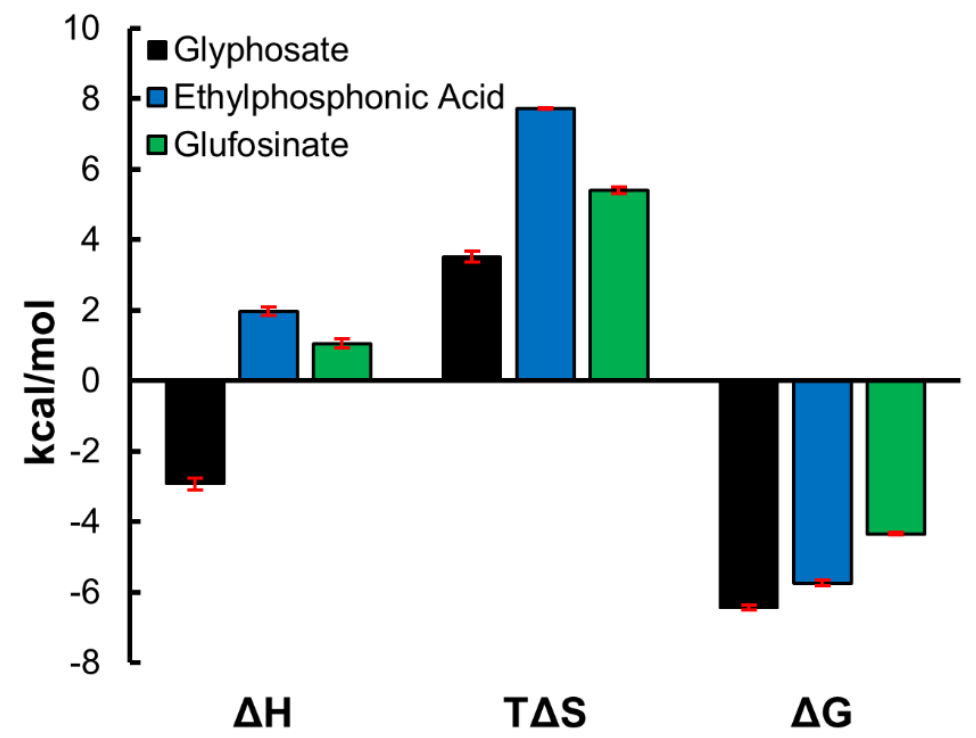

Figure S16. Graphical representation of thermodynamic parameters of adsorption for various analytes in NU-1000. 
Table S8. The thermodynamic parameters of ethylphosphonic acid binding in NU-1000, NU-901, and NU-1200.

\begin{tabular}{cccc}
\hline MOF & $\begin{array}{c}\Delta \mathbf{H} \\
(\mathbf{k c a l} / \mathbf{m o l})\end{array}$ & $\begin{array}{c}\mathbf{T} \Delta \mathbf{S} \\
(\mathbf{k c a l} / \mathbf{m o l})\end{array}$ & $\begin{array}{c}\Delta \mathbf{G} \\
(\mathbf{k c a l} / \mathbf{m o l})\end{array}$ \\
\hline NU-1000 & $2.0 \pm 0.1$ & $7.72 \pm 0.03$ & $-5.74 \pm 0.09$ \\
NU-901 & $1.4 \pm 0.1$ & $6.8 \pm 0.1$ & $-5.44 \pm 0.02$ \\
NU-1200 & $4.1 \pm 0.50$ & $9.3 \pm 0.5$ & $-5.18 \pm 0.07$ \\
\hline
\end{tabular}

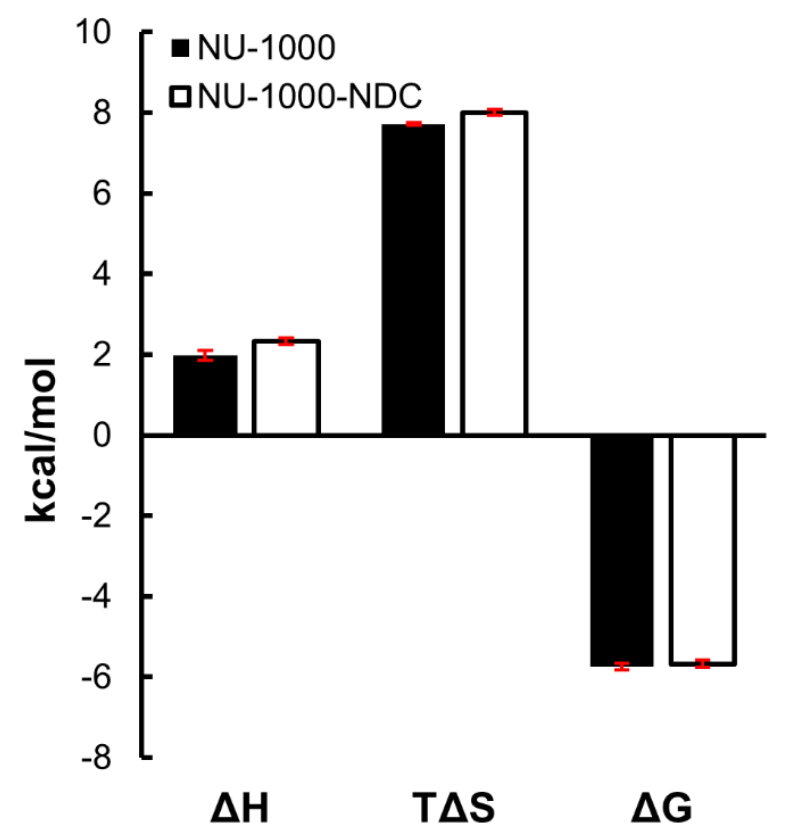

Figure S17. Thermodynamic parameters of ethylphosphonic acid binding in NU-1000 and NU-1000NDC. 

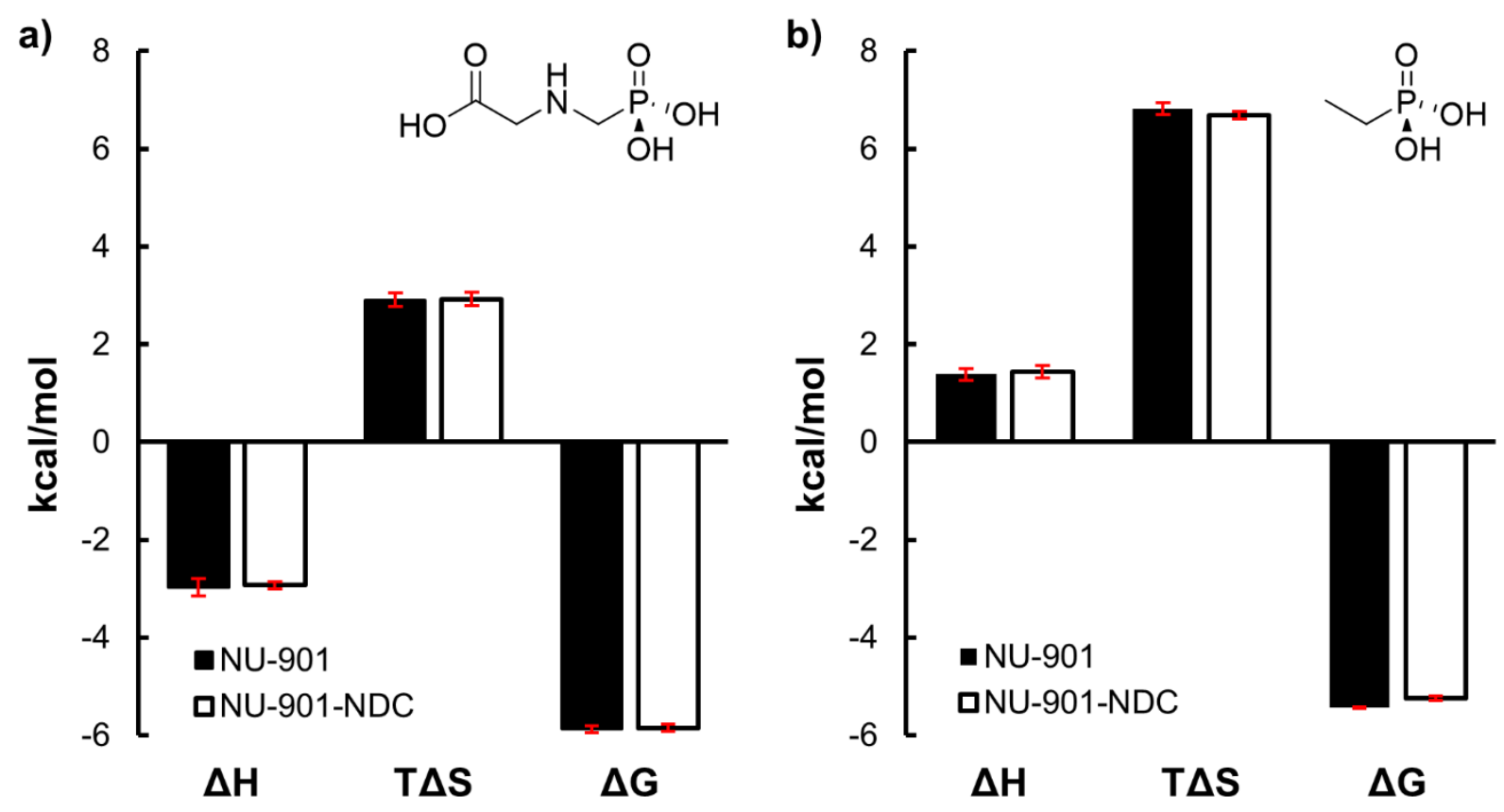

Figure S18. Thermodynamic parameters of a) glyphosate and b) ethylphosphonic acid binding in NU901 and NU-901-NDC.

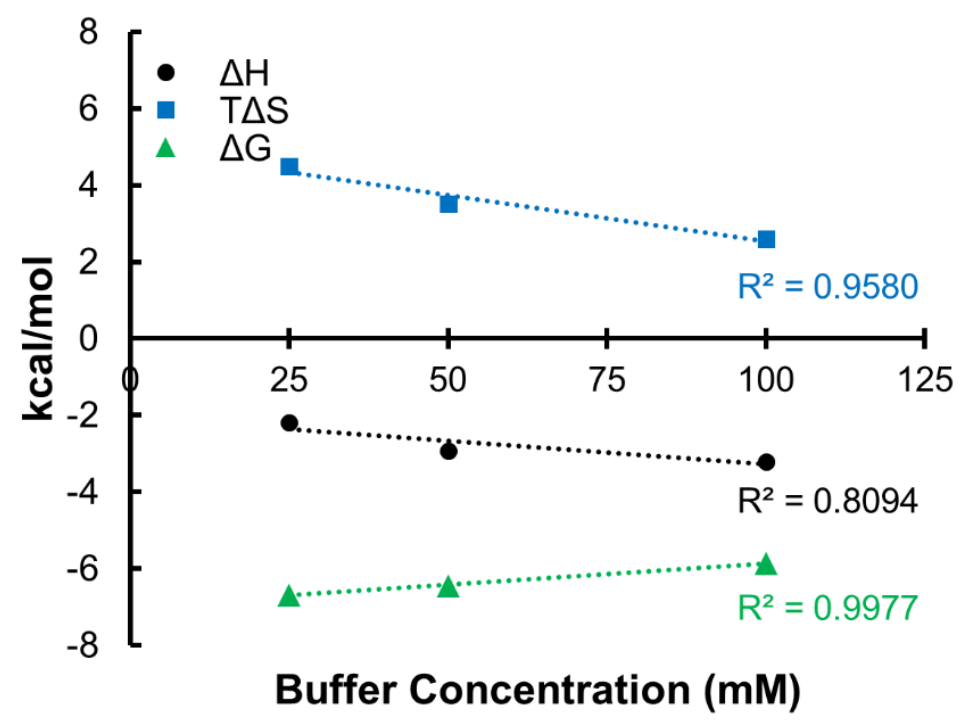

Figure S19. Scatter plot demonstrating the linear relationship between the thermodynamic parameters $(\Delta \mathrm{H}, \mathrm{T} \Delta \mathrm{S}$, and $\Delta \mathrm{G})$ of glyphosate binding in NU-1000 and buffer concentration. 


\section{DFT Energy-Minimized Structures}

a)

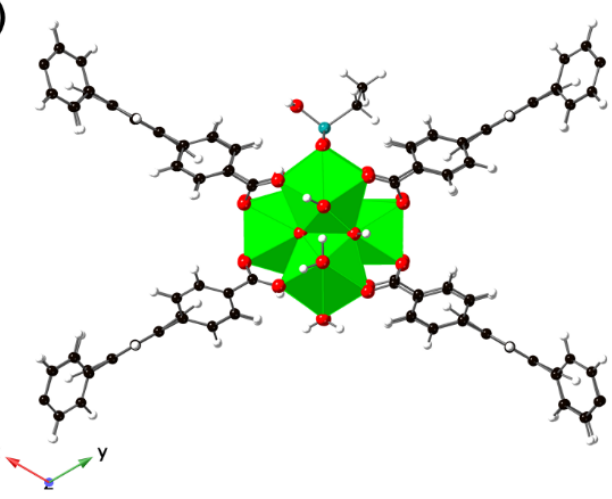

b)

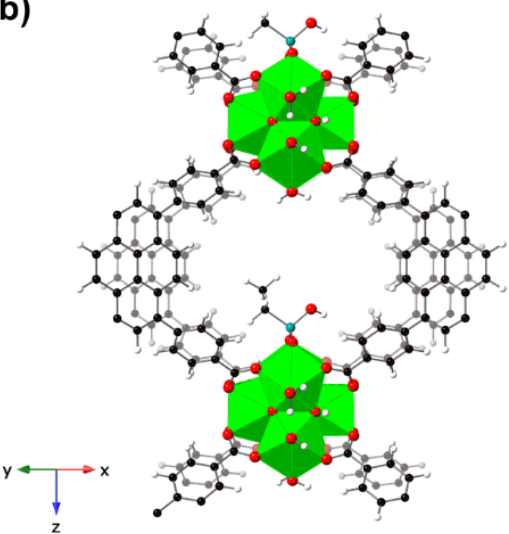

c)

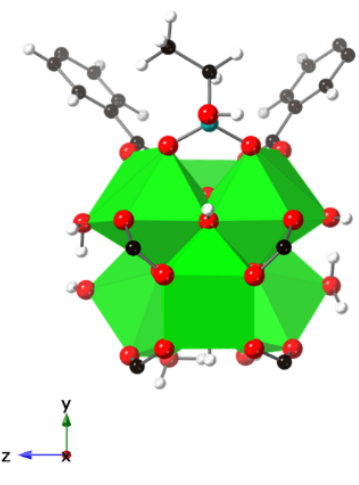

Figure S20. Lowest energy structural conformations of ethylphosphonic acid binding in a) the NU-1000 mesopore and $\mathrm{b}$ and $\mathrm{c}$ ) the NU-1000 c-pore.

a)

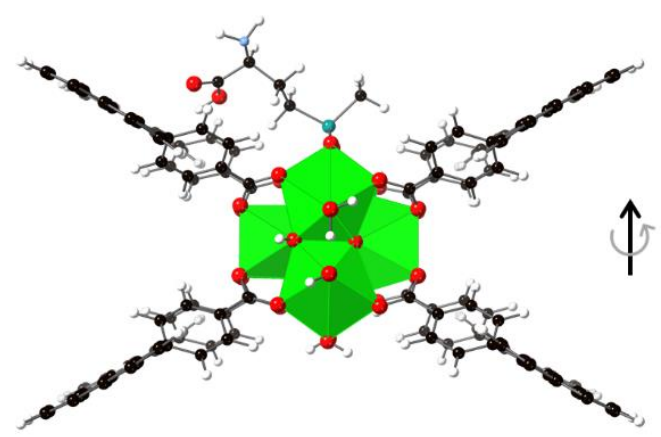

$r^{x}$ b)

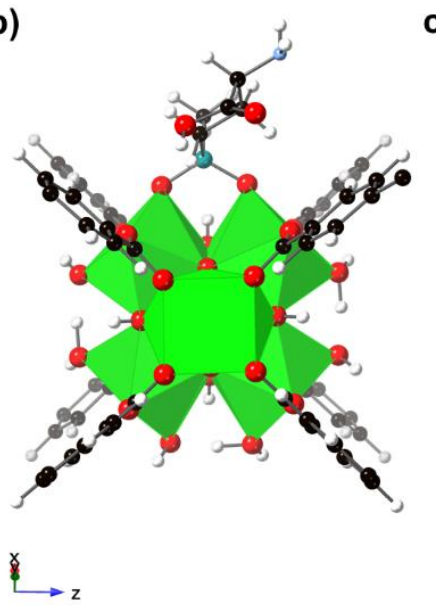

c)

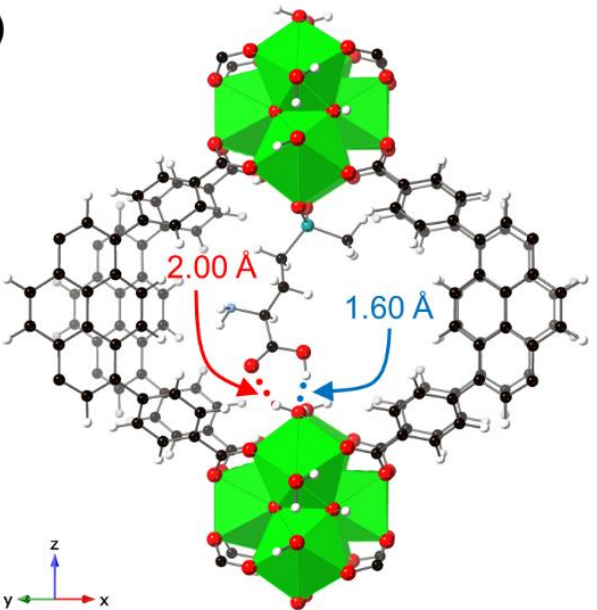

Figure S21. Lowest energy structural conformations of glufosinate binding in the NU-1000 mesopore a) looking down the c-axis and b) rotated $90^{\circ}$ around the axis shown and c) in the NU-1000 c-pore.

a)

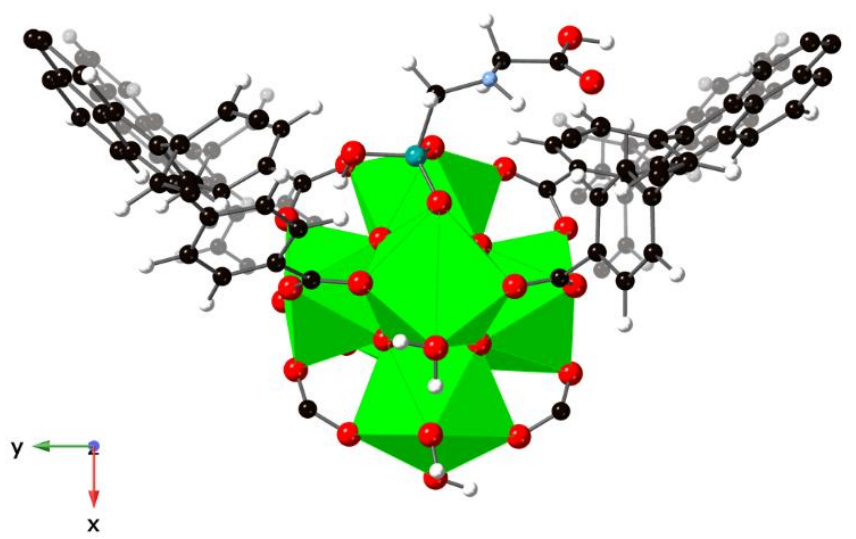

b)

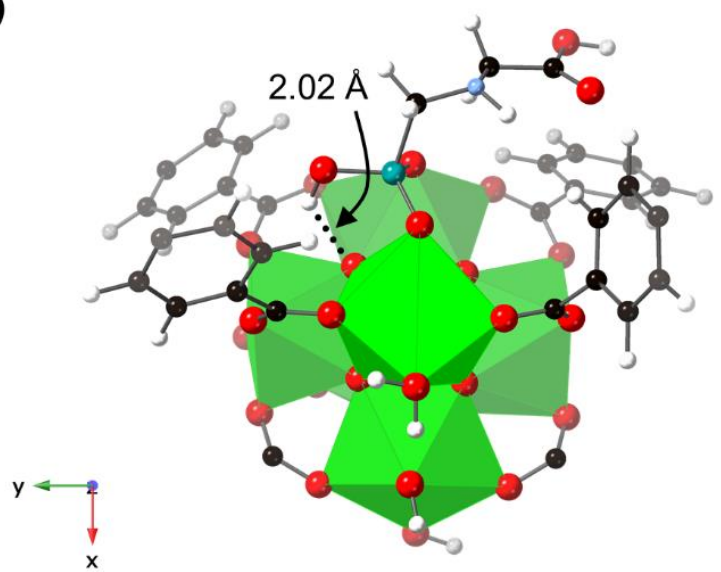

Figure S22. Lowest energy structural conformation of a) glyphosate binding in the diamond pore of NU-901 and b) trimmed figure of same conformation to show hydrogen bonding. 


\section{References}

1. Wang, T. C.; Vermeulen, N. A.; Kim, I. S.; Martinson, A. B.; Stoddart, J. F.; Hupp, J. T.; Farha, O. K., Scalable Synthesis and Post-Modification of a Mesoporous Metal-Organic Framework Called Nu-1000. Nat. Protoc. 2016, 11 (1), 149-62.

2. Islamoglu, T.; Otake, K.-i.; Li, P.; Buru, C. T.; Peters, A. W.; Akpinar, I.; Garibay, S. J.; Farha, O. K., Revisiting the Structural Homogeneity of Nu-1000, a Zr-Based Metal-Organic Framework. CrystEngComm 2018, 20 (39), 5913-5918.

3. Goswami, S.; Ray, D.; Otake, K.-i.; Kung, C.-W.; Garibay, S. J.; Islamoglu, T.; Atilgan, A.; Cui, Y.; Cramer, C. J.; Farha, O. K.; Hupp, J. T., A Porous, Electrically Conductive HexaZirconium(Iv) Metal-Organic Framework. Chem. Sci. 2018, 9 (19), 4477-4482.

4. Wang, X.; Zhang, X.; Li, P.; Otake, K.-i.; Cui, Y.; Lyu, J.; Krzyaniak, M. D.; Zhang, Y.; Li, Z.; Liu, J.; Buru, C. T.; Islamoglu, T.; Wasielewski, M. R.; Li, Z.; Farha, O. K., Vanadium Catalyst on Isostructural Transition Metal, Lanthanide, and Actinide Based Metal-Organic Frameworks for Alcohol Oxidation. J. Am. Chem. Soc. 2019, 141 (20), 8306-8314.

5. Peters, A. W.; Otake, K.; Platero-Prats, A. E.; Li, Z.; DeStefano, M. R.; Chapman, K. W.; Farha, O. K.; Hupp, J. T., Site-Directed Synthesis of Cobalt Oxide Clusters in a Metal-Organic Framework. ACS Appl. Mater. Interfaces 2018, 10 (17), 15073-15078. 